УДК $82: 81+372.3$

DOI:

Ганна Андрєєнкова, студентка II курсу ОС “Магістр”

Лариса Колодіна, кандидат філологічних наук, доцент кафедри романо-германських мов і перекладу Національного університету біоресурсів і природокористування Украӥни, м. Київ

\title{
КАЗКА ЯК МОТИВАЦІЙНИЙ ЧИННИК ДО ВИВЧЕННЯ АНГЛІЙСЬКОЇ МОВИ
}

Стаття присвячена дослідженню значення казки як мотиваційного чинника, який при належному психолого-педагогічному використанні спроможний сформувати стійкий пізнавальний інтерес до вивчення англійської мови у початковій школі. Зазначено, що вікова категорія молодших школярів є більш сприйнятливою саме до такого жанру літератури, оскільки казка є своєрідним поєднанням дитинства $i$ реалій дорослішання, способом занурення в англомовний світ персонажів з пробудженням емоцій співчуття, інтересу, творчого осмислення їх вчинків. Підкреслюється, щяо саме від нестандартно підібраних вчителем методів використання найрізноманітніших засобів візуалізачії казкових сюжетів буде залежати ступінь $i$ стійкість мотиваційного зачікавлення школярів до вивчення англійської мови.

Ключові слова: казка; мотив; мотивачія; англійська мова.

Jim. 10.

Hanna Andryeyenkova, the $I^{\text {st }}$ year Master Student Larysa Kolodina, Ph.D.(Philology), Associate Professor of the Romance and Germanic Languages and Translation Department National University of Life and Environmental Sciences of Ukraine, Kyiv

\section{FAIRY-TALE AS A MOTIVATIONAL FACTOR FOR LEARNING ENGLISH}

The article is devoted to the investigation of the meaning of fairy-tale as the motivational factor which with the assistance of proper psycho-pedagogical use can create a stable cognitive interest in learning the English language in the primary school. It worth mentioning that the main goal of the mentor in teaching the foreign language, including English, is the development of pupils' creative personality, desire, interest, and capability to become the participants of intercultural communication, improve the comprehensive knowledge in the field of foreign language. To solve this issue the teacher should capture child's interest and provide motivation to learn the subject. According to the researchers, children in the junior school years have the great opportunities to form the motivational field of the communication. Also, mostly in this age pupils comprehend a fairy-tale as this genre represents the association of childhood and reality of getting older, a way of the plunging into the characters' English world with the awakening of emotions as sympathy, interest, creative comprehension of their actions.

Considering the value of the motivation, one may note that the researchers gradually and in different manners interpret the meaning of motives. The great number of presented definitions facilitate to summarize its meaning and come to conclusion regarding the correlation between motive and motivation. Specifically, the unstandardized methods, which a teacher implements to use the most different ways to visualize the fairy-tale's plot, considerably influence the level and firmness of the pupil 's motivational interest in learning English.

Keywords: a faity-tale; motivation; the English language.

П остановка проблеми. Перший клас - це найважливіший етап для дитини, коли відбувається адаптація до шкільного процесу, знайомство $з$ шкільними предметами, новим середовищем та принципами навчання. Психологи та педагоги вважають, що у цей період на вчителя покладається низка обов'язків, серед яких найважливішуроль відіграє мотивування школярів до вивчення предмету [1]. Також головним завданням наставника у навчанні зокрема англійської мови стає розвиток особистості школярів щодо творчої діяльності, бажання та спроможності ставати учасниками міжкультурної комунікації, покращувати загальні знання усфері вивчення іноземної мови. Для того, щоб вирішити це питання, вчителеві необхідно зацікавити дитину та забезпечити стимулом до вивчення предмета.

Це означає, що в полі зору уваги вчителя виявляється не тільки навчання, яке здійснюється учнем, але й розвиток особистості учня, який відбувається в процесі навчання. Формування мотивації - це виховання в учнів ідеалів, світоглядних цінностей в поєднанні з активною поведінкою школяра, що означає взаємозв'язок усвідомлюваних і реально діючих мотивів, єдність слова і діла, активну життєву позицію школяра [4, 115]. Однак, щоб знання виховували, потрібно виховувати ставлення до самих знань. Це означає, що бажано в процесі навчання сформувати у школярів активне внутрішне ставлення до самих знань, до способів їх здобуття [5]. 
Аналіз основних досліджень, У психологопедагогічній науці дослідженням проблеми щодо виявлення вікових можливостей учнів початкової школи займалися вчені І.Д. Бех, В.В. Давидов, Т.В. Драгунова, Л.В. Занков, Д.Б. Ельконін, А.К. Маркова, В.О. Сухомлинський, П.М. Якобсон та інші. Вони довели, що молодший шкільний вік має великі резерви щодо формування мотиваційної сфери спілкування [8]. На сьогоднішній день багато дослідників підкреслюють актуальність врахування мотиваційного питання у педагогічному процесі. На думку Є. Ільїна, оскільки отримання освіти є обовязковою вимогою, то у педагогічній психології та педагогіці аспект мотивації до навчання вважається центральним [5, 253]. Як підкреслюють Т. Гребенюк та О. Гребенюк, для виявлення ефективних педагогічних методів розвитку у школярів інтересу до знань та бажання навчатися, необхідно насамперед 3'ясувати значення, роль i закономірність формування мотивів та мотиваційної сфери [4, 71]. Розглядаючи сутність мотивації, по-перше, необхідно з'ясувати значення “мотиву”. Як вважають Н. Бордовська та А. Реан “мотив - це внутрішнє спонукання особистості до того або іншого вияву активності (діяльність, спілкування, поведінка), пов'язане із задоволенням певної потреби" [1, 184]. За словами В. Каширіна та В. Сластьоніна, мотиви особистості є потребою або сукупністю потреб у функції спонукання. "Мотиви - це внутрішні психічні спонукання до діяльності, поведінки, зумовлені актуалізацією тих або інших потреб особистості". Мотиви зумовлені не тільки потребами людини, але й станом її підготовленості до дії та наявністю інших умов для успішного втілення поставлених задач у межах цих умов. У своїй сукупності мотиви складають мотивацію діяльності та поведінки особистості у певних обставинах $[8,75]$. Таким чином, система мотивів діяльності та поведінки складає основу мотивації. О. Литовченко дає таке визначення мотивації: "мотивація особистості зумовлена потребами, цілями, рівнем домагань, ідеалами, світоглядом, переконаннями, спрямованістю особистості, крім того такими суб' єктивними характеристиками, як уміння, знання, здібності, характер" [7, 268].

Проблема мотивації в навчальному процесі з'являється при вивченні будь-якого предмета шкільної програми. Зазвичай це пояснюється тим, що дитина увіці шести-семи років не усвідомлює, навіщо треба вчити англійську мову і тому має упереджене ставлення та небажання навчатися новому предмету. Саме у таких випадках учитель виступає в ролі мотиватора, який повинен подати свій предмет так, щоб якомога глибше зацікавити школярів у важливості вивчення англійської мови та культури. Якщо вчителеві вдається швидко та ефективно прищепити інтерес класу, то навчальний процес надалі проходитиме успішно та результативно. Через це навчальні посібники та відповідні методики пропонують дієві способи для пробудження та стимулювання мотивації 3 урахуванням специфіки того чи іншого предмета. Відомо, що узвичайних закладах освіти проблема незацікавленості до вивчення іноземних мов має наздвичайно гострий характер у порівнянні зі спеціалізованими школами, гімназіями або ліцеями.

Мета статті - проаналізувати роль казки як мотиваційного чинника та засобу підвищення мотивації до навчання англійської мови в учнів молодшого шкільного віку. Досягнення мети передбачає вирішення таких завдань: 1) узагальнити педагогічний досвід щодо формування у молодших школярів позитивної мотивації та інтересу до вивчення англійської мови на початковому етапі навчання; 2) на прикладі вивчення казок виявити й описати найефективніші засоби підвищення мотивації до навчання англійської мови в молодшому шкільному віці.

Виклад основного матеріалу. На думку психологів, діти у віці п'яти-семи років вже спроможні сприйняти й засвоїти велику кількість інформації. Але саме ту інформацію, яка на їхній погляд цікава і викликає надзвичайний інтерес [6, 12]. Це означає, що усі діти можуть засвоювати великий обсяг матеріалу, але для цього їм потрібна підтримка і допомога. У закладах середньої освіти таке завдання покладається на плечі вчителя.

Зазвичай на першому етапі навчання, коли дитина тільки прийшла до школи, вона ще не має свідомого уявлення про те, навіщо вона має вчитися і яка мета іiі перебування у закладі середньої освіти. Можна припустити, що така поведінка пов'язана з тим, що не всім школярам подобається шкільний процес. А саме, вони вважають його або занадто складним або просто не мають мотивації до опанування нових знань. У такому випадку педагог виступає у ролі помічника і стимулятора мотивації здобувачів освіти. Саме в початковий шкільний період вчитель повинен створити стійку мотивацію та чітке розуміння дитиною процесу вивчення англійської мови. Одним із ефективних мотиваційних методів вважається використання казок для вивчення іноземної мови.

Як свідчать дослідження, якщо діти мають інтерес до навчання, то вони швидко опановують 


\section{КАЗКА ЯК МОТИВАЦЙНИЙ ЧИННИК ДО ВИВЧЕННЯ АНГЛЙСЬКОЇ МОВИ}

матеріал і легко виконують завдання. Таким чином, у них добре формуються мовні навички. Для того, щоб сприяти цьому процесу, вчитель має проводити урок, керуючись сучасними ефективними методами. Урок іноземної мови у початковій школі обов' язково має бути насичений наочністю. До цього зобов'язує той факт, що домінуючим у цьому віці $є$ образне мислення. У зв'язку з цим будь-яке дидактично доцільне і методично виправдане використання предметного або картинного унаочнення, яке методично доцільно супроводжує певну іншомовну лексичну одиницю (слово, словосполучення), зв' язне мікровисловлювання, яке $\epsilon$ ефективним засобом впливу на пам'ять і процес усвідомлення значення такої одиниці. Психологи довели, що в учнів початкової школи переважає мимовільна увага, тому недоцільно у навчанні повною мірою розраховувати лише на довільну увагу, яка вимагає значних вольових зусиль [2]. Тому визначальною умовою привернення уваги у цьому віці $є$ широке застосування яскравих ілюстрацій, тобто засобів навчання, що впливають на мимовільну увагу, особливо через яскраве зорове унаочнення (напр., сюжети казок, ілюстрації з головними героями або пейзажними замальовками, розмальовки). Саме такі засоби можна вважати цілком адекватними цілям і завданням навчання у початковій школі. Багато уваги на уроках іноземної мови варто приділяти використанню цікавого, яскравого наочного матеріалу, що підвищує ритм заняття, а отже, й інтерес, тобто безпосередньо впливає на мотивацію до навчання [9]. Наприклад, ігрові технології, рольові казки, вибіркові діалоги, інтегровані уроки сприяють формуванню зацікавленості до вивчення англійської мови. Більше того, заняття 3 використанням комп'ютерних технологій для перегляду казок, перегляд трейлерів до мультфільмів, слайд-шоу 3 уривками казок та наочного матеріалу також сприяють залученню учнів до опанування предмета у комфортній, пізнавальній та цікавій формі. Вчитель повинен пам'ятати, що створення мотиваційної сфери - це, насамперед, формування таких умов, які створюють внутрішнє спонукання школярів до навчання, забезпечують усвідомлення подальшого саморозвитку мотивації $[3,94]$. Слід також розвивати і мотивацію колективних досягнень. Цього можна досягти шляхом залучення дітей до парної і групової роботи. Результат колективної діяльності залежить від готовності кожного члена колективу додати власні зусилля до досягнення загальної мети.

Саме казка великою мірою сприяє формуванню мотивації до опанування іноземною мовою, адже завдяки своєму цікавому змісту вона завжди привертає увагу дітей. Захоплюючий сюжет творів цього жанру дозволяє школярам проникнути у надзвичайний світ іноземної мови, познайомитися з іiї фонетичними особливостями, дізнатися про народних героїв тієї країни, родом з якої ця казка. Світ казок $є$ своєрідним "містком" між дитинством і реаліями життя. Цей цілком прийнятний мотиваційний засіб здатний активізувати будь-якого учня.

Використання казок на уроках англійської мови уже давно стало предметом особливої уваги методистів, педагогів-практиків, науковців. Використання казки для творчої розповіді досліджували О. Фльорина, П. Воробйов, О. Ушакова. Застосування казки як інсценівки, гри під час формування іншомовної компетентності учнів вивчали В. Мовсесян, В. Белоусов, Л. Топольницька. Науковці дійшли висновку, що казки є засобом розвитку мовлення учнів, їх літературно-творчих здібностей $[10,65]$. Незважаючи на те, що про значення казок для розвитку особистості дитини написано дуже багато, окремого методичного чи наукового дослідження, яке б давало вичерпну інформацію про ефективність використання казок на уроках англійської мови, не зроблено. Це й посилює значимість досліджуваної теми, над якою ми продовжуємо працювати.

Висновки та перспективи подальших досліджень. Дослідження використання казки як мотиваційного чинника на уроках англійської мови зумовлене необхідністю пошуку нових підходів до активізації учнівського пізнавального інтересу до вивчення іноземної мови, акумуляції усіх можливих ресурсів, спрямованих на розвиток іншомовної компетентності вихованця сучасної школи, зростанням попиту на іншомовні навички.

Беззаперечно, заняття, яке будується на сюжеті певної казки, одразу приречене на успіх. Адже для учнів такий прийом зовсім незвичний у порівнянні з усталеним шкільним процесом. Тому завдяки нестандартній формі подачі матеріалу вчитель привертає увагу школярів до навчання. Під час слухання казки дитина молодшого шкільного віку візуалізує фантастичних героїв, оцінює їх вчинки, відчуває їхнє існування як у реальному житті, переживає за них та співчуває. Розвиток уяви стає поштовхом до формування фантазії й інтересу, а отже, мотивацією до самостійної та колективної творчої діяльності школярів.

Таким чином, при використанні казки як мотиваційного знаряддя на уроці англійської мови вчитель може розраховувати на дієвість 
нестандартного підходу до розвитку фантазії дітей, формування їх емоційної сфери, раціонального сприйняття, пробудження інтересу до навчального процессу, а отже, й успішного опанування фонетичних основ англійської мови.

\section{ЛІТЕРАТУРА}

1. Бордовская Н. В. Педагогика: учебник для вузов / Н. В. Бордовская, А. А. Реан. - СПб.: Питер, 2000. - 304 с.

2. Власюк Л. С. Казка як засіб формування позитивної мотивації при вивчення англійської мови: методична розробка / Л.С. Власюк, Н.Л. Савчук, Ж.І. Куровська // Міський методичний кабінет. Нововолинська загальноосвітня школа I-III ступенів №4, 2014. - 116 с.

3. Галушка Г.М. Формуємо соціокультурну компетенцію за допомогою казок / Г.М. Галушка. - Харків: Основа, 2008. - 94 с.

4. Гребенюк О. С. Основы педагогики индивидуальности / О. С. Гребенюк, Т. Б. Гребенюк. - M., 2004. - 456 c.

5. Ильин Е. П. Мотивация и мотивы / Е. П. Ильин. - СПб.: Питер, 2002. - 512 с.

6. Каруцяк С. Розвиток пізнавальної активності молодших школярів на уроках англійської мови / С. Каруцяк // English. - 2011. - № 18. - С. 12.

7. Литовченко О. В. Специфіка мотивації творчої особистості підлітка (теоретичний аспект) / О. В. Литовченко // Теоретико-методичні проблеми виховання дітей та учнівської молоді: зб. наук. праць. - К., 2008. - Вип. 12, кн. 1. C. 265-271.

8. Сластенин В. А. Педагогика и психология: учеб. пособие для студ. высш. учеб. заведений / В. А. Сластенин, В. П Каширин. - М.: Изд. центр “Академия", 2001. - 480 с.

9. Стребна О. В. Інтерактивні методи навчання в практиці роботи початкової школи / О. В. Стребна, А. О. Соценко. - Х.: Основа, 2008. - 176 с.

10. Стрельченко К. Використання народних казок у процесі навчання англійської мови / К. Стрельченко // Іноземні мови. - 2012. - №3. - С.65.

\section{REFERENCES}

1. Bordovskaia, N. V. \& Rean, A. A. (2000). Pedahohyka: uchebnyk dlia vuzov [Pedagogy: a textbook for high schools]. Sankt Peterburg: Pyter, 304p. [in Russian].
2. Vlasiuk, L. S., Savchuk, N.L. \& Kurovska, Zh.I. (2014). Kazka yak zasib formuvannia pozytyvnoi motyvatsii pry vyvchennia anhliiskoi movy: metodychna rozrobka [Fairy-tale as a means of formation of positive motivation in the study of English: methodical development]. Miskyi metodychnyi kabinet. Novovolynska zahalnoosvitnia shkola I-III stupeniv no.4, 116 p. [in Ukrainian].

3. Halushka, H.M. (2008). Formuiemo sotsiokulturnu kompetentsiiu za dopomohoiu kazok [We form socio-cultural competence with fairy-tales]. Kharkiv: Osnova, 94 p. [in Ukrainian].

4. Hrebeniuk, O. S. \& Hrebeniuk, T. B. (2004). Osnovy pedahohyky yndyvydualnosty [Fundamentals of pedagogy of individuality]. Moskva, $456 \mathrm{p}$. [in Russian].

5. Ylyn, E. P. (2002). Motyvatsyia y motyvy [Motivation and motivation ]. Sankt Peterburg: Pyter, 512 p. [in Russian].

6. Karutsiak, S. (2011). Rozvytok piznavalnoi aktyvnosti molodshykh shkoliariv na urokakh anhliiskoi movy [Development of cognitive activity of junior pupils in English lessons]. English. Kyiv, no.18, p. 12. [in Ukrainian].

7. Lytovchenko, O. V. (2008). Spetsyfika motyvatsii tvorchoi osobystosti pidlitka (teoretychnyi aspekt) [Specificity of the motivation of the teenager's creative personality (theoretical aspect)]. Teoretyko-metodychni problemy vykhovannia ditei ta uchnivskoi molodi: zb. nauk. prats. Kyiv, vol. 12, no. 1, pp. 265-271. [in Ukrainian].

8. Slastenyn, V. A. (2001). Pedahohyka y psykholohyia: ucheb. posobye dlia stud. vblssh. ucheb. zavedenyi [Pedagogy and Psychology: textbook. allowance for stud. supreme. training. establishments]. Moskva: Akademyia, 480 p. [in Russian].

9. Strebna, O. V. \& Sotsenko, A. O. (2008). Interaktyvni metody navchannia $v$ praktytsi roboty pochatkovoi shkoly [Interactive methods for navigating in the practice of robotics]. Kharkiv: Osnova, 176p. [in Ukrainian].

10. Strelchenko, K. (2012). Vykorystannia narodnykh kazok u protsesi navchannia anhliiskoi movy [Using folk tales in the process of learning English]. Inozemni movy, no. 3, p.65. [in Ukrainian].

Стаття надійшла до редакції 11.04.2018

\section{G58089

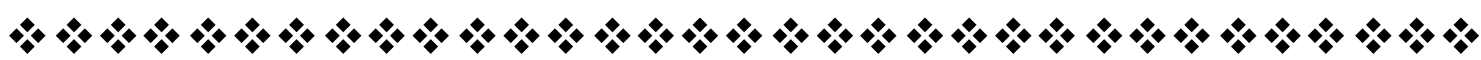

